\title{
Effect of Various Immersion Time and Water Temperature on Seed Germination of Clitoria ternatea and Momordica charantia
}

\author{
Nur Asmira Md Salleh ${ }^{1}$ and Furzani Pa'ee ${ }^{1,2 *}$ \\ ${ }^{1}$ Faculty of Applied Sciences and Technology, Universiti Tun Hussein Onn Malaysia Pagoh, KM1, \\ Jalan Panchor, 84600 Muar, Johor, Malaysia \\ ${ }^{2}$ Center of Research Sustainable Uses of Natural Resources, Universiti Tun Hussein Onn Malaysia Pagoh, \\ KM1, Jalan Panchor, 84600 Muar, Johor, Malaysia
}

\begin{abstract}
The seeds of Clitoria ternatea and Momordica charantia were subjected to seven presowing treatments, i.e., control $\left(\mathrm{T}_{0}\right)$, peeled coat and soaked in $5{ }^{\circ} \mathrm{C}$ for 24 hours $\left(\mathrm{T}_{1}\right)$, peeled coat and soaked in $37^{\circ} \mathrm{C}$ for 24 hours $\left(\mathrm{T}_{2}\right)$, peeled coat and soaked in $5{ }^{\circ} \mathrm{C}$ for 48 hours $\left(\mathrm{T}_{3}\right)$, peeled coat and soaked in $37{ }^{\circ} \mathrm{C}$ for 48 hours $\left(\mathrm{T}_{4}\right)$, peeled coat and soaked in $5{ }^{\circ} \mathrm{C}$ for 48 hours $\left(\mathrm{T}_{5}\right)$, peeled coat and soaked in $37{ }^{\circ} \mathrm{C}$ for 72 hours $\left(\mathrm{T}_{6}\right)$. The study revealed that peeling the coat and soaking seeds in water for various temperatures and periods improved seed germination. The highest germination and germination energy percentage of $C$. ternatea were observed in $\mathrm{T}_{2}$, namely $94.95 \%$ and $23.69 \%$, respectively, while the lowest germination $(0 \%)$ and germination energy $(0 \%)$ was found in $\mathrm{T}_{6}$. The highest germination and germination energy percentage of $M$. charantia, namely $64.38 \%$, and $16.10 \%$, respectively, were found in $\mathrm{T}_{3}$, while the lowest germination (10.67\%) and germination energy $(2.17 \%)$ were observed in $\mathrm{T}_{0}$. The germination may vary for both

ARTICLE INFO

Article history:

Received: 18 April 2021

Accepted: 8 August 2021

Published: 29 September 2021

seeds used in the study as C. ternatea and $M$. charantia are different in type. The presowing treatments of seeds would prove its potential in the practical fields.
\end{abstract}

DOI: https://doi.org/10.47836/pjtas.44.4.03

E-mail addresses:

nurasmiramdsalleh@gmail.com (Nur Asmira Md Salleh)

furzani@uthm.edu.my (Furzani Pa'ee)

*Corresponding author
Keywords: Clitoria ternatea, germination, herbal plants, Momordica charantia, seed germination 


\section{INTRODUCTION}

Herbal medicinal plants have been used as a significant source for the cure of human ailments since time immemorial, and as such, they had a significant impact on global health (Nimesh, 2018; Patwekar et al., 2016).

Medicinal herbs have become popular worldwide in the latter half of the $20^{\text {th }}$ century due to the widespread recognition of the value of conventional medicines and the integration of natural source derivatives in pharmaceuticals (Alsarhan et al., 2014). In addition, Enioutina et al. (2017) stated that in many developed countries, herbal remedies had been accepted as an essential and alternative remedy under strict regulations and oversight (Alsarhan et al., 2014) because they are more effective, healthy, and have fewer side effects than modern medicine.

Clitoria ternatea L., also known as butterfly pea, is a plant that belongs to the Fabaceae family and has been used traditionally for various medicinal purposes (G. K. Kumar \& Thomas, 2012). Furthermore, C. ternatea is a very wellknown herb used in Ayurvedic medicine for different ailments. Ayurvedic 'Medya Rasayana' is a rejuvenating recipe mainly containing extracts from $C$. ternatea and is specially designed to treat patients' neurological disorders. It is also used to enhance intellect (G. K. Kumar \& Thomas, 2012). Nguyen et al. (2011) added that cliotides could be found in all the parts of this plant. Cliotides are the peptides that have potent anti-microbial properties against Escherichia coli.
Momordica charantia is a flowering vine known as bitter gourd or bitter melon, belongs to the Cucurbitaceae family (D. S. Kumar et al., 2010). The bitter gourd fruits are used as a tonic, stomachic, stimulant, emetic, antibilious, laxative, and alterative in Ayuverdic medicine. Momordica charantia has been used in numerous Asian traditional medicine systems for a long time. Bitter gourd, like other bitter-tasting foods, stimulates digestion. According to clinical experience and traditional reports, $M$. charantia rarely has harmful effects because it is a demulcent and mild inflammation modulator.

Orthodox and recalcitrant seeds resulted from pollen grains' ovule double fertilization (Rajjou et al., 2012). Seed germination begins with the mature seed absorbing water and ends with the emergence of the embryo via the surrounding structures (Nonogaki et al., 2010). One of the vital agricultural goals is to achieve rapid and uniform germination and seedling emergence when seeds are sown. The seed industry uses priming treatments to improve the efficiency of commercial seed lots. These treatments include regulated seed ingestion followed by dehydration to their original water content to enable storage. These treatments are thought to enhance the pre-germinative metabolic process, implying that the primed seeds germinate faster than untreated seeds. The seeds are mostly more or less ellipsoid and often pitted or rugulose in a pattern of drying. The seed coat with woody exotesta of several layers is derived from the outer integument and papery endotesta (Corner, 
1976). The coat of the individual seed is often watertight. Each seed contains a large embryo and little endosperm. The seeds are often germinated quickly once the seed coat is punctured (The Seed Site, 2013). However, literature examining the effect of seed priming treatments of $C$. ternatea and $M$. charantiais is scarce. Therefore, the study was conducted to investigate the effect of pre-sowing treatments on the germination of C. ternatea and M. charantia to add knowledge in this field.

\section{MATERIALS AND METHODS}

\section{Seed Collection and Preparation}

Seeds of $C$. ternatea and $M$. charantia were collected from the residents of Pagoh and Simpang Renggam, respectively, in Johor. Uniform seed sizes from each species were selected for the treatments to reduce non-treatments variation because seed size is a crucial plant trait that affects seed germination and further seedling establishment (Mog et al., 2017). The present study was conducted in batches under controlled conditions for three months, from July to September 2018. The parameters of the study were water temperature and time immersion. The pre-sowing treatments used in the study were based on Hossain et al. (2005) with a slight modification as stated in Table 1.

Table 1

Pre-sowing treatments of seeds

\begin{tabular}{ll}
\hline No. & Pre-sowing treatments \\
\hline $\mathrm{T}_{0}$ & Control (intact seeds without peeling coat and soaking) \\
$\mathrm{T}_{1}$ & Peeled coat and soaked seeds in $5{ }^{\circ} \mathrm{C}$ for 24 hours \\
$\mathrm{T}_{2}$ & Peeled coat and soaked seeds in $37^{\circ} \mathrm{C}$ for 24 hours \\
$\mathrm{T}_{3}$ & Peeled coat and soaked seeds in $5{ }^{\circ} \mathrm{C}$ for 48 hours \\
$\mathrm{T}_{4}$ & Peeled coat and soaked seeds in $37^{\circ} \mathrm{C}$ for 48 hours \\
$\mathrm{T}_{5}$ & Peeled coat and soaked seeds in $5{ }^{\circ} \mathrm{C}$ for 72 hours \\
$\mathrm{T}_{6}$ & Peeled coat and soaked seeds in $37^{\circ} \mathrm{C}$ for 72 hours \\
\hline
\end{tabular}

Three replicates of 50 seeds each were used for testing the germination. The seeds were placed on the top of a filter paper soaked with distilled water in Petri dishes (5 seeds per Petri dish). Water was replenished as needed. All the Petri dishes were left at room temperature. The effects of pre-sowing treatments were assessed periodically by counting germinated seeds. The first and final counts were taken on days 2 and 14, respectively. The mean from all batches was recorded as a result. 
Germination (\%), Germination Energy (\%), and Germination Period

The germination period was recorded. The germination, defined as the development of a plant from seed after a period of dormancy, was calculated. The germination energy was also determined, defined as the germination percentages at the peak of daily germination.
In addition, germination energy is also used as a measure of germination pace. It was thought to be an indicator of the vigor of the seedling. The germination (\%) (1), germination energy (\%) (2), and germination period (3) were calculated using the formula cited by Czabator's index (1962):

$$
\begin{aligned}
& \text { Germination }=\frac{\text { Total number of seeds germinated }}{\text { Total number of seeds in all replicates }} \times 100 \\
& \text { Germination energy }=\frac{\text { Number of seed germinated daily }}{\text { Total number of seeds in all replicates }} \times 100
\end{aligned}
$$$$
\text { Germination period }=\text { Days to } \text { maximum seeds germination }
$$

\section{Statistical Analysis}

Data were statistically analyzed by using Microsoft Excel to evaluate the potential treatment differences. The analysis of variance (ANOVA) at $\alpha=0.05$ and the means separation were also included for the analysis in this study.

\section{RESULTS}

The seed germination of C. ternatea started on day two after the sowing and continued up to the next 14 days. Rapid germination was found in most treatments except for $\mathrm{T}_{5}$ (uncoated and soaked seeds in $5{ }^{\circ} \mathrm{C}$ for 72 hours) and $\mathrm{T}_{6}$ (uncoated and soaked seeds in $37{ }^{\circ} \mathrm{C}$ for 72 hours), as stated in Table 2. The seeds in $T_{5}$ germinated on day four after sowing, while seeds in $T_{6}$ were not germinated.
For C. ternatea, germination and germination energy differed significantly for seeds given different pre-sowing treatments (one-way ANOVA: $\mathrm{F}_{(6,42)}=872.31, P<$ 0.0001 for germination, $\mathrm{F}_{(6,42)}=881.57$, $P<0.0001$ for germination energy). The highest germination $(\%)(94.95 \pm 3.81)$ and germination energy $(\%)(23.69 \pm 0.91)$ of C. ternatea were recorded in $\mathrm{T}_{2}$ (uncoated and soaked seeds in $37^{\circ} \mathrm{C}$ for 24 hours) followed by $\mathrm{T}_{4}$ (uncoated and soaked seeds in $37{ }^{\circ} \mathrm{C}$ for 48 hours), $\mathrm{T}_{1}$ (uncoated and soaked seeds in $5{ }^{\circ} \mathrm{C}$ for 24 hours), $\mathrm{T}_{0}$ (untreated), $\mathrm{T}_{3}$ (uncoated and soaked seeds in $5^{\circ} \mathrm{C}$ for 48 hours), and $\mathrm{T}_{5}$ (uncoated and soaked seeds in $5^{\circ} \mathrm{C}$ for 72 hours) (Tables 2 and 3 ). 
Table 2

Mean germination (\%) of Clitoria ternatea at different treatments

\begin{tabular}{lccccccc}
\hline \multirow{2}{*}{ Days } & \multicolumn{7}{c}{ Treatments } \\
\cline { 2 - 8 } & $\mathrm{T}_{0}$ & $\mathrm{~T}_{1}$ & $\mathrm{~T}_{2}$ & $\mathrm{~T}_{3}$ & $\mathrm{~T}_{4}$ & $\mathrm{~T}_{5}$ & $\mathrm{~T}_{6}$ \\
\hline 2 & 2.67 & 19.33 & 96.67 & 0 & 45.33 & 0 & 0 \\
4 & 4.00 & 21.33 & 98.00 & 0.67 & 46.67 & 0 & 0 \\
6 & 4.67 & 22.67 & 98.67 & 0.67 & 55.33 & 0 & 0 \\
8 & 4.67 & 20.00 & 98.00 & 0.67 & 64.67 & 0.67 & 0 \\
10 & 5.33 & 18.67 & 93.33 & 0.67 & 62.00 & 0.67 & 0 \\
12 & 6.00 & 18.67 & 90.00 & 1.33 & 60.00 & 0.67 & 0 \\
14 & 6.00 & 17.33 & 90.00 & 1.33 & 59.33 & 0.67 & 0 \\
\hline \multirow{2}{*}{ Mean } & $4.76 \pm$ & $19.71 \pm$ & $94.95 \pm$ & $0.76 \pm$ & $56.19 \pm$ & $0.38 \pm$ & $0 \pm 0$ \\
\hline
\end{tabular}

Note. $*$ Significant different at $\alpha=0.05$

Table 3

Mean germination energy (\%) of Clitoria ternatea at different treatments

\begin{tabular}{lccccccc}
\hline \multirow{2}{*}{ Days } & \multicolumn{7}{c}{ Treatments } \\
\cline { 2 - 8 } & $\mathrm{T}_{0}$ & $\mathrm{~T}_{1}$ & $\mathrm{~T}_{2}$ & $\mathrm{~T}_{3}$ & $\mathrm{~T}_{4}$ & $\mathrm{~T}_{5}$ & $\mathrm{~T}_{6}$ \\
\hline 2 & 0.67 & 4.83 & 24.17 & 0 & 11.33 & 0 & 0 \\
4 & 1.00 & 5.33 & 24.50 & 0.17 & 11.67 & 0 & 0 \\
6 & 1.17 & 5.67 & 24.67 & 0.17 & 13.83 & 0 & 0 \\
8 & 1.17 & 5.00 & 24.17 & 0.17 & 16.17 & 0.17 & 0 \\
10 & 1.33 & 4.67 & 23.33 & 0.17 & 15.50 & 0.17 & 0 \\
12 & 1.50 & 4.67 & 22.50 & 0.33 & 15.00 & 0.17 & 0 \\
14 & 1.50 & 4.33 & 22.50 & 0.33 & 14.83 & 0.17 & 0 \\
\hline \multirow{2}{*}{ Mean } & $1.19 \pm$ & $4.93 \pm$ & $23.69 \pm$ & $0.19 \pm$ & $14.05 \pm$ & $0.10 \pm$ & 0 \\
& 0.29 & $0.45^{*}$ & $0.92^{*}$ & 0.11 & $1.88^{*}$ & 0.09 & $0 \pm 0$ \\
\hline
\end{tabular}

Note. * Significant different at $\alpha=0.05$

For M. charantia, germination and $<0.0001$ for germination energy). The germination energy differed significantly for highest germination (\%) and germination seeds given different pre-sowing treatments energy (\%) of $M$. charantia are $64.38 \pm 5.21$ (one-way ANOVA: $\mathrm{F}_{(6,42)}=60.39, P<$ and $16.10 \pm 1.30$ respectively found in $\mathrm{T}_{3}$ 0.0001 for germination, $\mathrm{F}_{(6,42)}=60.38, P$ (uncoated and soaked seeds in $5{ }^{\circ} \mathrm{C}$ for 48 
hours), followed by $\mathrm{T}_{5}$ (uncoated and soaked soaked seeds in $37{ }^{\circ} \mathrm{C}$ for 48 hours), and seeds in $5{ }^{\circ} \mathrm{C}$ for 72 hours), $\mathrm{T}_{1}$ (uncoated the lowest germination (\%) (10.67 \pm 8.08$)$ and soaked seeds in $5{ }^{\circ} \mathrm{C}$ for 24 hours), $\mathrm{T}_{6}$ and germination energy (\%) (2.67 \pm 2.02$)$ (uncoated and soaked seeds in $37^{\circ} \mathrm{C}$ for 72 was recorded in $\mathrm{T}_{0}$ (untreated seeds) (Tables hours), $\mathrm{T}_{2}$ (uncoated and soaked seeds in 4 and 5).

$37^{\circ} \mathrm{C}$ for 24 hours), and $\mathrm{T}_{4}$ (uncoated and

Table 4

Mean germination (\%) of Momordica charantia at different treatments

\begin{tabular}{lccccccc}
\hline \multirow{2}{*}{ Days } & \multicolumn{7}{c}{ Treatments } \\
\cline { 2 - 8 } & $\mathrm{T}_{0}$ & $\mathrm{~T}_{1}$ & $\mathrm{~T}_{2}$ & $\mathrm{~T}_{3}$ & $\mathrm{~T}_{4}$ & $\mathrm{~T}_{5}$ & $\mathrm{~T}_{6}$ \\
\hline 2 & 0 & 30.00 & 3.33 & 55.33 & 4.00 & 24.67 & 10.00 \\
4 & 1.33 & 34.67 & 6.00 & 60.00 & 6.67 & 36.00 & 18.00 \\
6 & 7.33 & 38.67 & 13.33 & 62.67 & 14.67 & 48.00 & 26.00 \\
8 & 11.33 & 38.67 & 15.33 & 68.67 & 14.67 & 48.00 & 31.33 \\
10 & 16.00 & 40.00 & 16.67 & 68.67 & 15.33 & 46.00 & 31.33 \\
12 & 18.67 & 42.00 & 18.67 & 68.00 & 15.33 & 44.00 & 30.00 \\
14 & 20.00 & 44.00 & 20.67 & 67.33 & 16.67 & 42.00 & 29.33 \\
\hline \multirow{2}{*}{ Mean } & $10.67 \pm$ & $38.29 \pm$ & $13.43 \pm$ & $64.38 \pm$ & $12.48 \pm$ & $41.24 \pm$ & $25.14 \pm$ \\
& $8.08^{*}$ & $4.68^{*}$ & $6.47^{*}$ & $5.21^{*}$ & $4.98^{*}$ & $8.41^{*}$ & $8.15^{*}$ \\
\hline
\end{tabular}

Note. * Significant different at $\alpha=0.05$

Table 5

Mean germination energy (\%) of Momordica charantia at different treatments

\begin{tabular}{lccccccc}
\hline \multirow{2}{*}{ Days } & \multicolumn{7}{c}{ Treatments } \\
\cline { 2 - 8 } & $\mathrm{T}_{0}$ & $\mathrm{~T}_{1}$ & $\mathrm{~T}_{2}$ & $\mathrm{~T}_{3}$ & $\mathrm{~T}_{4}$ & $\mathrm{~T}_{5}$ & $\mathrm{~T}_{6}$ \\
\hline 2 & 0 & 7.50 & 0.83 & 13.83 & 1.00 & 6.17 & 2.50 \\
4 & 0.33 & 8.67 & 1.50 & 15.00 & 1.67 & 9.00 & 4.50 \\
6 & 1.83 & 9.67 & 3.33 & 15.67 & 3.67 & 12.00 & 6.50 \\
8 & 2.83 & 9.67 & 3.83 & 17.17 & 3.67 & 12.00 & 7.83 \\
10 & 4.00 & 10.00 & 4.17 & 17.17 & 3.83 & 11.5 & 7.83 \\
12 & 4.67 & 10.50 & 4.67 & 17.00 & 3.83 & 11.00 & 7.50 \\
14 & 5.00 & 11.00 & 5.17 & 16.83 & 4.17 & 10.50 & 7.33 \\
\hline \multirow{2}{*}{ Mean } & $2.67 \pm$ & $9.57 \pm$ & $3.36 \pm$ & $16.10 \pm$ & $3.12 \pm$ & $10.31 \pm$ & $6.28 \pm$ \\
& $2.02^{*}$ & $1.17^{*}$ & $1.62^{*}$ & $1.30^{*}$ & $1.25^{*}$ & $2.10^{*}$ & $2.04^{*}$ \\
\hline
\end{tabular}

Note. * Significant different at $\alpha=0.05$ 


\section{DISCUSSION}

Based on the results, it seems that water temperature and time immersions were critical factors in C. ternatea and $M$. charantia seeds as reported by D. S. Kumar et al. (2010) and Hossain et al. (2005) in Terminalia chebula and Andrographis paniculata. Many research have been carried out to develop effective seed treatments methods to break the dormancy and accelerate the germination rate (Hossain et al., 2005). The seeds must be subjected to physical and chemical treatments to artificially achieve rapid and synchronous germination (Azad et al., 2010). These include uncoating seeds at both ends by piercing, nicking, filling, or clipping (Catalan \& Macchiaveloli, 1991) and soaking the seeds in different water temperatures, different time immersion, and different concentrations of acid treatments (Kobmoo \& Hellum, 1984).

Generally, temperature influenced germination in three ways: moisture, hormone development, and enzyme activity. The seeds must imbibe water to germinate, so enough moisture is available (Dove, 2010). Seeds with hard coats have improved germination when treated before sowing (Hossain et al., 2005). Hossain et al. (2005) added that the drupes germinate slowly and irregularly from untreated seeds. The study's findings show that uncoated seeds of C. ternatea soaked in warm water ( 37 ${ }^{\circ} \mathrm{C}$ ) increased germination and germination energy. Around $95 \%$ of $C$. ternatea seeds germinate after being clipped at the end so that the embryo is not harmed and soaked in warm water for 24 hours. G. K. Kumar and Thomas (2012) have shown that seeds of $A$. paniculata, pre-treated by soaking in $35^{\circ} \mathrm{C}$ water, showed up to $80 \%$ germination. The study results for C. ternatea also supported G. K. Kumar and Thomas (2012). On the other hand, the study results for M. charantia supported the finding of Hossain et al. (2005). Hossain et al. (2005) have shown that the seeds of $T$. chebula, pre-treated by soaking in cold water for 48 hours, provides the highest germination value (4.41) and germination energy (58.9\%).

\section{CONCLUSION}

From the study, it can be concluded that pre-sowing treatments of seeds would prove its potential in the practical fields. Among the treatments applied in the experiment for Clitoria ternatea are that seeds that were depulped at two ends and soaked in $37^{\circ} \mathrm{C}$ for 24 hours $\left(\mathrm{T}_{2}\right)$ were found more effective to rate germination percentage and energy. In contrast, the seeds of Momordica charantia were effectively germinated in $\mathrm{T}_{3}$ (uncoated and soaked seeds at $5{ }^{\circ} \mathrm{C}$ for 48 hours). In addition, it can be concluded that germination may vary for both seeds used in the study as the seeds of C. ternatea and $M$. charantia are different in type.

\section{ACKNOWLEDGEMENTS}

This research was supported by the Ministry of Higher Education (MOHE) through Fundamental Research Grant Scheme for Research Acculturation of Early Career Researchers (FRGS - RACER) (RACER/1/2019/WAB13/UTHM/1) and 
Universiti Tun Hussein Onn Malaysia (UTHM) through Geran Penyelidikan Pascasiswazah (GPPS) Vot (H631).

\section{CONFLICT OF INTEREST}

The authors declare no conflict of interest.

\section{REFERENCES}

Alsarhan, A., Sultana, N., Al-Khatib, A., \& Kadir, M. R. A. (2014). Review on some Malaysian traditional medicinal plants with therapeutic properties. Journal of Basic and Applied Sciences, 10, 149-159. http://doi. org/10.6000/1927-5129.2014.10.20

Azad, M. S., Zedan-Al-Musa, M., \& Matin, M. A. (2010). Effects of pre-sowing treatments on seed germination of Melia azedarach. Journal of Forestry Research, 21(2), 193-196. http://doi. org/10.1007/s11676-010-0031-1

Catalan, L. A., \& Macchiaveloli, R. (1991). Improving germination in Prosopis flexuosa D. C. and P. alba Griseb. with hot water treatments and scarification. Seed Science and Technology, 19(2), 253-262.

Corner, E. J. H. (1976). The seeds of dicotyledons (Vol. 1). Cambridge University Press.

Czabator, F. J. (1962). Germination value: An index combining speed and completeness of pine seed germination. Forest Science, 8(4), 386-396.

Dove, N. (2010). The effect of increasing temperature on germination of native plant species in the North Woods region. https://underc.nd.edu/ assets/156376/fullsize/dove2010.pdf

Enioutina, E. Y., Salis, E. R., Job, K. M., Gubarev, M. I., Krepkova, L. V., \& Sherwin, C. M. (2017). Herbal medicines: Challenges in the modern world. Part 5. Status and current directions of complementary and alternative herbal medicine worldwide. Expert Review of
Clinical Pharmacology, 10(3), 327-338. https:// doi.org/10.1080/17512433.2017.1268917

Hossain, M. A., Arefin, M. K., Khan, B. M., \& Rahman, M. A. (2005). Effects of seed treatments on germination and seedling growth attributes of Horitaki (Terminalia chebula Retz.) in the nursery. Research Journal of Agriculture and Biological Sciences, 1(2), 135-141.

Kobmoo, B., \& Hellum, A. K. (1984). Hot water and acid improve the germination of Cassia siamea Britt. seeds. The Embryan, 1(1), 27-33.

Kumar, D. S., Sharathnath, K. V., Yogeswaran, P., Harani, A., Sudhakar, K., Sudha, P., \& Banji, D. (2010). A medicinal potency of Momordica charantia. International Journal of Pharmaceutical Sciences Review and Research, 1(2), 95-100.

Kumar, G. K., \& Thomas, T. D. (2012). High frequency somatic embryogenesis and synthetic seed production in Clitoria ternatea Linn. Plant Cell, Tissue and Organ Culture, 110(1), 141-151. https://doi.org/10.1007/s11240-012-0138-5

Mog, B., Nayak, J. A. M., \& Mohana, G. S. (2017). Germination and seedling establishment in cashew (Anacardium occidentale L.): An interaction between seed size, relative growth rate and seedling biomass. Journal of Plantation Crops, 45(2), 110-120.

Nguyen, G. K. T., Zhang, S., Nguyen, N. T. K., Nguyen, P. Q. T., Chiu, M. S., Hardjojo, A., \& Tam, J. P. (2011). Discovery and characterization of novel cyclotides originated from chimeric precursors consisting of albumin-1 chain a and cyclotide domains in the Fabaceae family. Journal of Biological Chemistry, 286(27), 24275-24287. https://doi.org/10.1074\%2Fjbc.M111.229922

Nimesh, S. (2018). Herbal drug is better than allopathic drug in the treatment of rheumatoid arthritis. International Journal of Pharmacognosy, 5(9), 539-545. 
Nonogaki, H., Bassel, G. W., \& Bewley, J. D. Rajjou, L., Duval, M., Gallardo, K., Catusse, J., Bally, (2010). Germination-Still a mystery. Plant Science, 179(6), 574-581. https://doi. org/10.1016/j.plantsci.2010.02.010

Patwekar, S. L., Suryawanshi, A. B., Gaikwad, M. J., Job, C., \& Job, D. (2012). Seed germination and vigor. Annual Review of Plant Biology, 63, 507-533. https://doi.org/10.1146/annurevarplant-042811-105550

S., Pedewad, S. R., \& Potulwar, A. P. (2016). Standardization of herbal drugs: An overview.

The Seed Site. (2013). Leguminosae. http://theseedsite. The Pharma Innovation Journal, 4(9), 100-104. co.uk/leguminosae.html 
